\title{
Verbal and Visual Signs of Advertisement in National Geographic Traveller Magazine
}

\author{
I Gede Putu Okta Prawiranatha \\ English Department - Faculty of Arts - Udayana University \\ [oktaprawiranatha02@gmail.com]
}

\begin{abstract}
This article is entitled "Verbal and Visual Signs of Advertisement in National Geographic Traveller Magazine". The aims are to describe the meaning and function of verbal and visual signs and how their interrelations are. The source of the National Geographic Traveller Magazine from which the three advertisements are selected, these selections are due to advertisements present good combination of colors, pictures and word choices than another advertisement which also consist of verbal and visual signs. The research is done through library research with documentation method and observation technique was applied to collect the data, the qualitative method was used to analyze the data based on the theory of meaning and function by Leech, theory of signs by Chandler, and use of color by Cerrato. The result of the analysis shows that the advertiser tends to use conceptual meaning and informational function to deliver or give information to the readers about the product itself. The verbal and visual signs are related to one another, verbal sign as the part that describes what is meant by visual sign and the visual sign as the part that illustrates what is meant by the verbal sign. So, what is shown in the visual sign is appropriate with what is written in the verbal sign and vice versa.
\end{abstract}

Keywords: meaning and function, verbal and visual signs, advertisement.

\begin{abstract}
Abstrak
Judul dari article ini adalah “"Verbal and Visual Signs of Advertisement in National Geographic Traveller Magazine”. Tujuannya adalah untuk mendeskripsikan makna dan fungsi dari tanda verbal dan visual dan bagaimana interrelasinya. Sumbernya dari majalah perjalanan National Geographic Traveller dimana hanya 3 iklan yang dipilih, karena iklan tersebut menyajikan kombinasi yang baik antara warna, gambar dan pilihan kata daripada iklan lain yang juga terdiri dari tanda-tanda verbal dan visual. Penelitian ini dilakukan melalui penelitian kepustakaan dengan metode dokumentasi dan teknik observasi yang digunakan untuk mengumpulkan data, metode kualitatif digunakan untuk menganalisis data berdasarkan teori makna dan fungsi oleh Leech, teori tanda oleh Chandler, dan penggunaan warna. oleh Cerrato. Hasil analisis menunjukkan bahwa pengiklan cenderung menggunakan makna konseptual dan fungsi informasi untuk menyampaikan atau memberikan informasi kepada pembaca tentang produknya. Juga menunjukan tanda verbal dan visual terkait satu sama lain, tanda verbal sebagai bagian yang menggambarkan apa yang dimaksud oleh tanda visual dan tanda visual sebagai bagian yang menggambarkan apa yang dimaksud oleh tanda verbal. Jadi, apa yang ditunjukkan pada tanda visual sesuai dengan apa yang tertulis di tanda verbal dan sebaliknya.
\end{abstract}

Kata kunci: makna dan fungsi, tanda verbal dan visual, iklan. 


\section{Background of The Study}

Saussure cited in Chandler (2001:28) defines a sign as the composition of a "signifier" and "signified". Signifier is the form which the sign takes. Signified is the concept it represents both in verbal and visual. In the advertisement verbal signs are about texts used to describe the product itself and the advertiser has to choose the proper words to make a good language because the words in advertisement give explanation or information about the product itself. And visual signs are about the picture or something that we can see.

In this modern era, advertisement exists everywhere because we can find advertisement everywhere, like at the street, in front of a store, in a magazine, newspaper, and also in social media. The advertisement has a primary purpose to introduce products to the public in order to attract the target audience to buy and use the products. So, to achieve those goals, advertiser has to create interesting advertisement containing verbal signs such as a good language or sentence which takes an important role to give explanation and information about the product itself, and visual signs such as the picture of the product, the logo of the company, and the colour of the advertisement, because picture or visual signs can make people easier to understand the meaning of the advertisement.

\section{Problems of The Study}

Based on the background above, there are two problems that can be formulated in this study:

a. What meanings and functions are conveyed by the verbal and visual signs in the selected advertisements?

b. How are the verbal and visual signs interrelated in the selected advertisements?

\section{Aims of the study}

According to the problems, the aims of the study are as follows:

a. To describe the meanings and functions conveyed by the verbal and visual signs in the selected advertisements.

b. To find out how are the verbal and visual signs interrelated in the selected advertisements.

\section{Research Method}

The research method is the process used to collect information and data for the purpose of doing research. This research collected the data directly from the source, and the method is the way or process and the procedures to approach the problems and find the answers because the data can be found, collected, and analyzed for the purpose.

\subsection{Data Source}

The data of this study were taken from the magazine entitled National Geographic Traveller UK edition/May 2017. There are 3 selected advertisements from the magazine for this study, the advertisements are chosen based on the standard components of printed advertisements by Leech (1966:54). The three advertisements were selected because those have almost all standard components of printed advertisement, and provides some data needed for this study.

\subsection{Method and Technique of Collecting Data}

In this study, the data were collected through observation and documentary methods. The first step was downloading the magazine from emagazinepdf.com, then observing the magazine to find out the advertisement, and selecting some advertisements based on the composition of verbal and visual signs. The selected advertisement was observed again to find 
out the composition of signs in the advertisement using note taking technique.

\subsection{Method and Technique of Analyzing Data}

Descriptive method was used to describe the advertisements and give a clear description through some theories and perspective. The first step of the analysis was putting the collected data to the table, and then classifying the data based on the composition of verbal and visual signs. Second, the data were analyzed based on relevant theories: Theory of meaning and function by Leech (1974), the theory of signs by Ferdinand de Saussure as cited in Chandler (2001:28) and Use of Color by Cerrato (2012:4). The last step was comparing the signs found in the selected advertisement to find out the relation between verbal and visual signs.

\section{Analysis}

\subsection{Christopher Ward C60 Trident Pro 600 GMT}

Christopher Ward C60 Trident Pro 600 GMT. Christopher Ward is a British luxury watch company, founded by Chris Ward, Mike France and Peter Ellis in 2004.

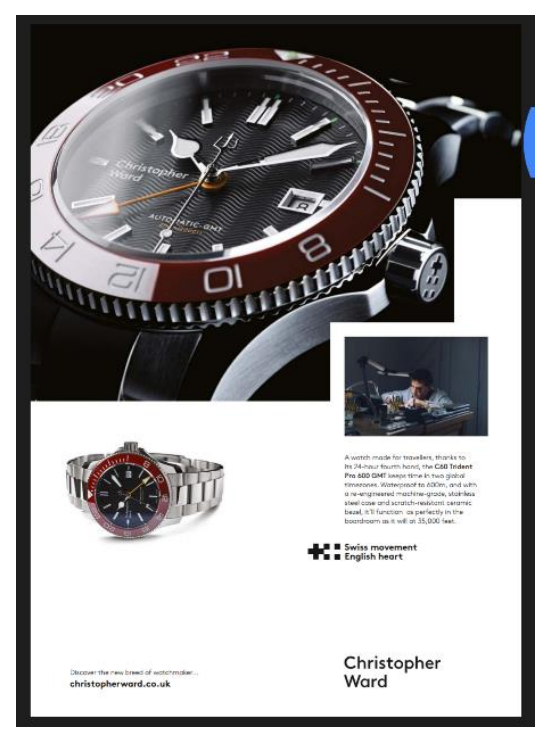

\subsubsection{The Analysis of Verbal Signs}

a. Headline

Headlines are one of the most important aspects of any advertising campaign. In this ad, the sentence "Christopher Ward" is categorized as Headline. Because this sentence is the most important aspect of this advertisement, and also greatly stealing attention because of the larger size than another sentence.

The headline is located at the bottom left of the ads and written in bold typestyle in black. This headline reflects the conceptual meaning and informational function because it shows the real meaning to inform or give the information to the readers about the name of the brand. So by looking at this verbal sign, the reader will know that the advertisement is about "Christopher Ward" product.

b. Body Copy

The body copy of this ads is located in the Centre - left of the page. The sentences "A watch made for travellers, thanks to its 24-hour fourth hand, the C60 Trident Pro 600 GMT keeps time in two global time zones. Waterproof to $600 \mathrm{~m}$, and with a re-engineered machinegrade, stainless steel case, and scratch resistant ceramic bezel, it'll function as perfectly in the boardroom as it will at 35,000 feet" conveys the information about the model of the watch named C60 Trident Pro 600 GMT which had various features like GMT, waterproof, machinegrade, stainless steel case and scratchresistant ceramic bezel.

The body copy reflects the conceptual meaning and informational function because it shows the real meaning about the features and quality of the product and also gives the information about the product features from writer to the readers.

c. Signature Line (Logo) 
The signature line $(\log )$ of this advertisement is in the form of the name of the brand and the slogan of the brand. They are described as follows:

- "Christopher Ward"

The sentence "Christopher Ward" in the ads also categorized as a signature line (logo) because it mentions the name of the brand. This sentence also reflects the conceptual meaning and informational function because it shown the real meaning and give an information to the readers about the brand name.

- "Swiss movement, English hearth"

This sentence is categorized as a signature line (logo) because it mentions the slogan of the brand. "Swiss movement, English hearth" also reflects connotative meaning because the sentence does not represent the real meaning. "Swiss movement, English hearth" means that the watch product is designed in England but it is manufactured in Switzerland. The sentence also has an informational function because the sentence informs the place where the product is made and manufacturer although it is not represented directly.

d. Standing Detail

The standing detail of this advertisement is "Discover the new breed of watchmaker... christopherward.co.uk" reflects the conceptual meaning and informational function because the writer wants to give an information to the readers about the official website of the brand and the readers can also find any further information about the brand and the product.

\subsubsection{The Analysis of Visual Signs \\ 5.1.2.1. Picture}

a. The big picture of the watch in the top part of the advertisement represents the details of C60 Trident Pro 600 GMT. By looking at the picture the readers can see the details of the clock more clearly.

b. The icon of the C60 Trident Pro 600 GMT in the centre - left part of the advertisement to represent the overall appearance and what the C60 Trident Pro 600 GMT look like. When looking at the picture the readers can recognize the product.

c. The picture of a man who made a watch in the right side of the advertisement represents that the watch from Christopher Ward is designed and engineered by highly talented craftspeople, so the watch product has a great quality.

d. The symbol beside the sentence "Swiss movement English heart" represents the logo of the brand. If looked at the symbol we will see a flag silhouette of England and Switzerland. So it also represents the sentence "Swiss movement English heart" that means that the watch is designed in England but it is manufactured in Switzerland.

\subsubsection{Colour}

a. Black in the product is the color of the watch face. The black color represents luxury and elegance. So the wearer of this watch looks more luxury and elegance.

b. Red in the product is the color of the bezel. This bezel can be rotated to adjust to GMT needle to know the time zone we want. The red color represents passion, so the wearer can get more passion when they wear C60 Trident Pro 600 GMT.

c. Silver in the product is the color of the body and the strap of the watch. This color is represented dignified and this color is also associated with prestige. So the wearer looks more dignified and raises the prestige of this watch users. 
d. White in this advertisement is the basic color. The white color is represented with simplicity and perfection. So when the readers look at this advertisement they will feel that the advertisement is simple but perfect.

\subsubsection{The Interrelation of Verbal and Visual Signs}

There is a good relationship between verbal and visual signs in this advertisement; they support each other to form an interesting advertisement to attract the target audiences. The verbal signs in this advertisement mention the features of the watch, brand name, and the website where the audiences can get any further information about the watch. And the visual signs are showing the design and the details of the watch.

In this advertisement, there are two pictures showing the design and details of the C60 Trident Pro 600 GMT. So by looking at the picture, the readers will know how the watch looks like and what features the watch has. The visual sign is supported by verbal sign especially in the body copy "A watch made for travellers, thanks to its 24-hour fourth hand, the C60 Trident Pro 600 GMT keeps time in two global time zones. Waterproof to $600 \mathrm{~m}$, and with a re-engineered machinegrade, stainless steel case, and scratch resistant ceramic bezel, it'll function as perfectly in the boardroom as it will at 35,000 feet." Where that body copy gives clearer information about what features that the watch has.

\section{Conclusions}

Based on the foregoing analysis and discussion, the following points can be concluded:

The result of data analysis in the first problem shows that the advertiser tends to use conceptual meaning and informational function to convey the meaning and deliver information to attract the interest of readers so they feel called to buy their products. The other meaning and function of language like connotative meaning, affective meaning, and expressive function were also used in the advertisements but not as much as conceptual meaning and informational function.

And the result of data analysis in the second problem shows that the verbal and visual signs are related to each other, each has an important role in shaping an advertisement in order to be meaningful. Verbal sign as the part that describes what is meant by visual sign and the visual sign illustrates what is meant by the verbal sign. So, what is shown in the visual sign is inappropriate with what is written in the verbal sign and vice versa.

\section{Bibliography}

Cerrato, Herman. (2012). The Meaning of Colors: How Colors Impact Our Daily Life In Business, Art, Work And Love. Chandler, Daniel. (2001). Semiotic for Beginners. Available from http://visualmemory.co.uk/daniel/Documents/S4B /

Dyer, Gillian. (1982). Advertising As Communication. New York: Methuen \& Co. Ltd.

Leech, G. (1966). English in Advertising a Linguistic Study of Advertising. Great Britain, London: Longman Group Limited.

Leech. G.N. (1974). Semantic The Study of Meaning. Penguin Books.

National Geographic Traveller. (2017). United Kingdom: National Geographic. 